\title{
THE RELATIONSHIP BETWEEN EMOTIONAL INTELLIGENCE AND JOB PERFORMANCE IN A CALL CENTRE ENVIRONMENT
}

\author{
H NEL \\ W S DE VILLIERS \\ Department of Industrial Psychology \\ University of Stellenbosch
}

\begin{abstract}
The objective of this study was to determine whether there is a relationship between emotional intelligence and job performance in a call centre environment. The sample comprised 135 call centre agents who worked in client services, sales and administrative environments in a life insurance company. The "Emotional Competency Inventory" that was completed by team leaders, was used as a measuring instrument and an overall job performance rating for each participant was provided by the participating organisation. Results show a statistically significant and positive correlation between emotional intelligence and job performance in the call centre environment. The strongest correlation with performance in the total call centre environment occurred in the cluster of selfmanagement and the emotional competency of self-confidence. It was further established that the combination of the emotional competencies emotional self-awareness, trustworthiness, self-confidence and influence explains the greatest degree of variance in job performance in the call centre environment as a whole.
\end{abstract}

\section{OPSOMMING}

Die doelstelling van hierdie studie was om te bepaal of daar ' $n$ verband tussen emosionele intelligensie en werkprestasie in ' $n$ oproepsentrum-omgewing bestaan. Die steekproef is saamgestel uit 135 oproepsentrum-agente van 'n lewensversekeringsmaatskappy wat in kliëntediens, verkoops- en administratiewe omgewings werksaam is. Die "Emotional Competency Inventory" wat voltooi is deur spanleiers, is as meetinstrument gebruik en 'n algehele werkprestasietelling vir elke deelnemer is deur die deelnemende organisasie verskaf. Resultate toon 'n statisties beduidende en positiewe korrelasie tussen emosionele intelligensie en werkprestasie in oproepsentrums. Die saamgestelde skaal van selfbestuur en die emosionele bevoegdheid selfvertroue toon die sterkste korrelasie met prestasie in die hele oproepsentrumomgewing. Verder is bevind dat die kombinasie van die emosionele bevoegdhede emosionele selfbewussyn, vertrouenswaardigheid, selfvertroue en invloed die meeste variansie in werksprestasie binne die hele oproepsentrum-omgewing verklaar.

In present-day society, quality of service and effective sales are fundamental to building sustained prosperity in organisations. Universally, client centeredness has become the primary focus of the business environment. Due to today's lower level of differentiation between competing products, customers choose service and support above product performance. Consequently the client has become the sole arbiter of organisational success (Armistead \& Clark, 1992; Barlow \& Maul, 2000; Gabbott \& Hogg, 1998). This different view has led to the establishment of call centres that enable organisations to offer a range of products and services to clients in an immediate, interactive and costeffective way (Nash, 1994).

\section{Call centres}

The call centre refers to the environment within an organisation where the telephone provides client support and/or a sales channel through which new business is generated and present business is retained (The Telephone comes to Life, 1995). Call centres enable organisations to achieve greater success in an increasingly competitive market. They are so prolific and the call centre environment places such high demands on employees (Cox, 1999; Queck, 1999) that this field of study deserves special attention.

Already in 2000 a substantial increase in the number of call centres was expected in Australia, the Far East, South America and South Africa over the following five years (Williams, 2000). Statistics and tendencies within the call centre industry in South Africa were published in a report produced by BMITechKnowledge in 1999. According to this report (South African Call Centre Industry Explodes, 1999), growth of some 14 percent per annum, which would create approximately 25,000 positions for call centre agents, was expected up to and inclusive of 2003. The need for working in shifts and the high labour turnover supported the prediction that up to 40,000 agents would have to

Requests for copies should be addressed to: WS De Villiers, Department of Industrial Psychology, University of Stellenbosch, Private Bag X1, Matieland, 7602 be recruited and trained to deal with the growth in call centre infrastructure in South Africa.

Aspects of the call centre environment, such as the constant technological change; opposition from clients; and working in shifts, place unique demands on employees (De Waal, 2004). In order to achieve success, call centre agents require specific attributes, such as the ability to maintain good customer relations and to convey enthusiasm about and faith in the products and the services offered. The call centre agent must also have active listening skills and be able to project his/her personality telephonically. The ability to adapt to fast-changing circumstances; to anticipate; and to deal with complaints is essential for success in this environment (De Waal, 2004). Due to the above-mentioned emotional demands, this career is characterised by a high incidence of burnout and equally high levels of absenteeism and staff turnover (Nash, 1994; The Telephone comes to Life, 1995; Williams, 2000).

From a managerial perspective the call centre manager is confronted with three vital challenges. Firstly, employees' levels of competence must be maintained through training, motivation and other situational variables such as remuneration and optimising of the physical work environment. Secondly, recruitment should focus on individuals showing the greatest potential to be successful within the call centre environment. Thirdly, an attempt must be made to address the huge internal threats facing call centres, namely staff absenteeism and high turnover (Armistead \& Clarke, 1992; Jacobson, 1998; Morrison, 1999).

\section{Emotional Intelligence}

Emotional intelligence can be defined as the ability to recognise one's emotions, as well as those of others, and as the ability to manage one's emotions, as well as those of others (Goleman, 1998; Salovey \& Mayer, 1990). The concept appears to have originated from two seemingly divergent concepts, namely 
emotion and intelligence. It is rooted in Leeper's perspective (Leeper 1948), which primarily views emotion as organising and motivating by nature, in contrast to the more traditional view of emotion as chaotic, disorganising and interfering in human behaviour (Arnold, 1970). Thorndike, as early as 1920, was the first psychologist to explore the arena of social intelligence. Social intelligence is defined as the competency to observe one's own and other people's emotional states, motives and behaviour, and to act favourably in relating to others on the grounds of this observation (Taylor, 1990). Gardner (1983) proposed a broader view of intelligence, suggesting a multiple construct constituting intrapersonal and interpersonal intelligence. The combination of interpersonal and intrapersonal intelligence is referred to as personal intelligence and it includes the concept of social intelligence. Salovey and Mayer (1990) integrated the concepts of social intelligence and constructive thinking to formulate the concept of emotional intelligence. In later publications they suggested that emotional intelligence should be seen as an ability or construct that can be divided into four branches: emotional perception and expression, emotional facilitation of thought, emotional understanding and emotional management (Salovey, Mayer \& Caruso in Snyder \& Lopez, 2002).

According to the model suggested by Goleman (1998), emotional intelligence is comprised of four clusters: selfawareness, self-management, social awareness and social skills. Self-awareness concerns the competency of recognising one's emotions, strengths and weaknesses, self-worth and capabilities. Self-management refers to managing one's internal states, impulses and resources. Social awareness comprises adeptness at recognising and responding to changes in the emotional states of other people by means of sensitivity and social self-confidence. Social skills can be defined as the effective handling of interpersonal relationships, to thereby induce desirable responses in others. Each of these clusters comprises various emotional competencies (see Table 1).

Emotional intelligence and job performance

The greatest challenges faced by organisations, including call centres, involve coping with constant change, being more creative, managing vast amounts of information, obtaining and retaining the right kind of people, increasing customer loyalty and improving cooperation (De Waal, 2004). According to Cherniss (2001) and others emotional intelligence plays a vital role in satisfying these requirements. For instance Boyatzis (1982) studied more than 2000 supervisors, middle managers and executives in 12 organisations and found that all but two of the 16 competencies that set star performers apart from average performers were emotional competencies. An analysis by Spencer and Spencer (1993) of job competencies in 286 organisations worldwide indicated that 18 of the 21 competencies in their generic model for distinguishing superior from average performers were emotional intelligencebased. Various recent research studies found emotional intelligence to be predictive of job performance in a wide variety of organisational contexts and roles (Abraham, 1999; Cavallo \& Brienza, 2002; Ryback, 1997; Servinc, 2001; Stagg \& Gunter, 2002; Vermeulen, 2004; Weisinger, 1998; Wong \& Law, 2002).

Call centres make high emotional demands on their employees and make a vital contribution to the economic success of present-day organisations (De Waal, 2004). However, there has been no specific research to date on the relationship between emotional intelligence and job performance within this environment. Hunter, Schmidt and Judiesch (1990) have reported that top performing insurance salespeople are 127 percent more productive than the average salesperson. Competency research in over 200 global companies and organisations had suggested that around one third of this difference was due to technical skill and cognitive ability, while two thirds resulted from emotional competence (Goleman, 1998). The Hay/McBer (Goleman, 1998) Research and Innovation Group performed research on insurance sales agents in 1997. This study found that those who were very strong in at least five of eight key emotional competencies sold policies worth more than double, the value of those sold by agents who were weak in these competencies.

TABLE 1

EMOTIONAL COMPETENCY FRAMEWORK

\begin{tabular}{|c|c|c|}
\hline & $\begin{array}{l}\text { Clusters with emotional } \\
\text { competencies }\end{array}$ & $\begin{array}{l}\text { Definition of emotional } \\
\text { competencies }\end{array}$ \\
\hline Recognition of & Self-awareness: & \\
\hline \multirow[t]{7}{*}{ Emotion } & Emotional self-awareness: & $\begin{array}{l}\text { Recognising one's emotions and } \\
\text { their effect }\end{array}$ \\
\hline & Accurate self-assessment: & $\begin{array}{l}\text { Knowing one's strengths and } \\
\text { limits }\end{array}$ \\
\hline & Self-confidence: & $\begin{array}{l}\text { Certainty about one's self-worth } \\
\text { and capabilities }\end{array}$ \\
\hline & Social-Awareness: & \\
\hline & Empathy: & $\begin{array}{l}\text { Understanding the feelings and } \\
\text { perspectives of others }\end{array}$ \\
\hline & Service orientation: & $\begin{array}{l}\text { Recognising and meeting } \\
\text { customers' needs }\end{array}$ \\
\hline & Organisational awareness: & $\begin{array}{l}\text { Reading a group's emotional } \\
\text { currents and power relations }\end{array}$ \\
\hline \multirow{16}{*}{$\begin{array}{l}\text { Management } \\
\text { of Emotion }\end{array}$} & Self-Management: & \\
\hline & Self-control: & $\begin{array}{l}\text { Managing disruptive emotions } \\
\text { and impulses }\end{array}$ \\
\hline & Trustworthiness: & $\begin{array}{l}\text { Maintaining standards of } \\
\text { honesty and integrity }\end{array}$ \\
\hline & Conscientiousness: & $\begin{array}{l}\text { Taking responsibility for } \\
\text { personal performance }\end{array}$ \\
\hline & Adaptability: & Flexibility in handling change \\
\hline & Achievement orientation: & $\begin{array}{l}\text { Striving to meet a standard of } \\
\text { excellence }\end{array}$ \\
\hline & Initiative: & $\begin{array}{l}\text { Readiness to act on } \\
\text { opportunities }\end{array}$ \\
\hline & Social Skills: & \\
\hline & Influence: & $\begin{array}{l}\text { Wielding effective tactics for } \\
\text { persuasion }\end{array}$ \\
\hline & Communication: & $\begin{array}{l}\text { Listening openly and sending } \\
\text { clear messages }\end{array}$ \\
\hline & Conflict management: & $\begin{array}{l}\text { Negotiating and resolving } \\
\text { disagreements }\end{array}$ \\
\hline & Leadership: & $\begin{array}{l}\text { Inspiring and guiding } \\
\text { individuals and groups }\end{array}$ \\
\hline & Change catalyst: & Initiating and managing change \\
\hline & Building bonds: & $\begin{array}{l}\text { Nurturing instrumental } \\
\text { relationships }\end{array}$ \\
\hline & $\begin{array}{l}\text { Teamwork and } \\
\text { collaboration: }\end{array}$ & $\begin{array}{l}\text { Working with others towards } \\
\text { shared goals }\end{array}$ \\
\hline & Developing others: & $\begin{array}{l}\text { Sensing others' development } \\
\text { needs and bolstering their } \\
\text { abilities }\end{array}$ \\
\hline
\end{tabular}

(Adapted from Goleman, 1998; Hay/McBer, 2002)

\section{The research problem and aim of the study}

Questions arise about whether there is a relationship between emotional intelligence and job performance within the call centre and which combination of emotional competencies could be regarded as the best predictors of success in this environment.

The aim of this study was, therefore, to establish whether there is a relationship between emotional intelligence and job performance within the call centre environment and to 
determine which combination of emotional competencies contribute most to performance.

The study attempted to answer the following research questions:

- Is there an association between emotional intelligence and job performance in the respective call centre environments of client services, sales and administration?

- Are there any differences in the strengths of association between emotional intelligence and job performance between the respective call centre environments of client services, sales and administration?

- Which clusters of emotional intelligence competencies show the strongest association with job performance in the respective call centre environments?

- Which emotional competencies show the strongest association with job performance in the respective call centre environments?

- Which combinations of emotional competencies serve as the best predictors of job performance in the total call centre environment, as well as in the client services, sales and administration environments respectively?

Answers to these questions may provide call centre managers with important predictors for future selection of call centre agents; guidelines for more effective training programmes; and possible solutions to the problem of absenteeism and turnover.

\section{METHOD}

\section{Sample}

The sample $(\mathrm{n}=135)$ was drawn from among call centre agents working at the head office of a major life insurance company situated in the Western Cape, South Africa. Randomised stratified sampling was used to select the participants (Babbie \& Mouton, 2001). The sample comprised call centre agents from client services (33\%), sales (34\%) and administrative (33\%) environments, all with a minimum service period of 12 months in their specific positions. The mean age of the subjects was 28 years and the gender ratio was $72 \%$ female and $28 \%$ male. The majority of the subjects $(75 \%)$ had a Grade 12 qualification, while $22 \%$ had obtained a diploma and $3 \%$ a university degree. The composition of the sample according to subjects' first language was random, but did appear to reflect the composition of the organisation as a whole. This included $70 \%$ Afrikaans-speaking, 23\% English-speaking and 7\% Xhosa-speaking call centre agents.

\section{Measurement}

Emotional intelligence was measured by means of the Emotional Competency Inventory (ECI) (Hay/McBer, 1999a). This is a multi-rater survey instrument based on the Self-Assessment Questionnaire (SAQ) developed by Boyatzis, the emotional competencies identified by Goleman (1998), as well as on competencies from Hay/McBer's Generic Competency Dictionary (Boyatzis, Goleman \& Rhee, 2000). The ECI encompasses 110 items within 20 competencies, divided into four clusters, namely self-awareness, self-management, social awareness and social skills (see Table 1).

The results render a total emotional intelligence score. The total score is then broken down into sub-scores for the four clusters and 20 different scores for the individual emotional competencies. Previous research has shown the ECI to have an overall average internal consistency coefficient of 0,85 for other ratings and 0,75 for self-ratings (Hay/McBer, 2002). Studies indicated that the ECI has satisfactory levels of validity (Burckle, 2000; Hay/McBer, 2002). Therefore, and since its administration is uncomplicated and it is specifically designed to assess emotional competence in the workplace, the ECI was the instrument of choice.
An overall job performance rating per individual was provided by the participating organisation. The rating was based, in part, on objective computer-assessed indices of job performance, such as the level of productivity on systems, closing rate of transactions, lapse index and amount of calls handled per hour. In addition, a subjective evaluation by supervisors of the quality of conversations with clients was used to calculate the total job performance rating. For reasons of confidentiality, the organisation was only willing to provide the total job performance rating for the purpose of this study and not the individual ratings of the respective variables. Data on the psychometric integrity of the performance ratings was not available.

\section{Procedure}

A total of 153 questionnaires were handed out and 135 were returned, resulting in a response rate of $88.2 \%$. This satisfying response rate might be ascribed to the fact that the team managers, who took part in the completion of the questionnaires, attended an information session during which the concept of emotional intelligence was explained and the structure of the questionnaire discussed. Management further took responsibility for ensuring timely completion of the questionnaires.

Although the ECI is a multi-rater survey instrument, time and cost constraints made self-evaluation or the use of more than one rater impossible. The subjects' team managers therefore completed the questionnaires. ECI ratings were obtained independently of performance ratings (at least with regards to the subjective component). The ideal, nonetheless, would have been to combine multiple ratings. This decision was supported by research (Fischer, 1998, Hay/McBer, 1999b; Hay/McBer; 2002) that showed that ratings of emotional intelligence by others were more stable and reliable than selfrating. There were 31 team managers, which yielded a ratio of 4.9 subjects per team manager. The total emotional intelligence score for each subject was calculated, as well as the average scores for the four clusters and the 20 emotional competencies.

\section{Statistical Analysis}

The correlation between variables was investigated with the use of Pearson's product moment correlation coefficient (Howell, 1992). Fisher's r-z transformation was used to transform the above-mentioned correlation coefficients to determine whether the correlation between the total emotional intelligence scores and job performance varied significantly within the different call centre environments, (Kendal \& Stuart, 1961). Multiple-regression was used to establish which combination of emotional competencies explained the largest amount of variance in job performance (Howell, 1992).

\section{RESULTS}

The results of this study revealed (Table 2) a statistically significant $(\mathrm{p}<0,01)$ and positive relationship $(\mathrm{r}=0,534)$ between total emotional intelligence scores and job performance in the call centre environment as a whole. Approximately $29 \%$ of the variance in job performance as measured by the specific performance measure could be explained in terms of variance in emotional intelligence as measured by the ECI. In the respective call centre environments, the following statistically significant and positive relationships between emotional intelligence and job performance were found: customer services $(r=0,559$; $\mathrm{p}<0,01)$, sales $(\mathrm{r}=0,419 ; \mathrm{p}<0,01)$ and administration $(\mathrm{r}=0,614$; $\mathrm{p}<0,01)$. 
TABLE 2

Pearson correlation COEFFeicients for total emotional INTELLIGENCE AND JOB PERFORMANCE

\begin{tabular}{lcc}
\hline Call Centre Environment & R & p \\
\hline Total Call Centre Environment & 0,534 & $<0,001$ \\
Client services & 0,559 & $<0,001$ \\
Sales & 0,419 & 0,002 \\
Administration & 0,641 & $<0,001$ \\
\hline
\end{tabular}

No statistically significant difference between the correlation coefficients of emotional intelligence and job performance in the respective call centre environments could be detected, as shown in Table 3.

TABLE 3

DIFFERENCES BETWEEN CORRELATIONS OF EMOTIONAI INTELLIGENCE AND JOB PERFORMANCE

\begin{tabular}{lcc}
\hline Call Centre Environments & Value of Test Statistic & p \\
\hline Client services vs. sales & $0,853(<1,96)$ & 0,394 \\
Sales vs. administration & $1,446(<1,96)$ & 0,148 \\
Administration vs. client services & $0,582(<1,96)$ & 0,560
\end{tabular}

Table 4 demonstrates that all four EQ clusters correlated significantly with performance in the total call centre environment and in each of the functional environments. Table 4 moreover demonstrates that the self-management cluster showed the strongest correlation with job performance in the total call centre environment, client services and the sales environments. The social skills cluster showed the strongest correlation with the agent's job performance in the administrative environment.

\section{TABLe 4}

Pearson correlation Coefficients for Clusters of EMOTIONAL INTELLIGENCE AND JOB PERFORMANCE

\begin{tabular}{lccccccccc}
\hline $\begin{array}{l}\text { Call Centre } \\
\text { Environment }\end{array}$ & $\begin{array}{c}\text { Self- } \\
\text { Awareness }\end{array}$ & $\begin{array}{c}\text { Self- } \\
\text { Management }\end{array}$ & $\begin{array}{c}\text { Social } \\
\text { Awareness }\end{array}$ & \multicolumn{2}{c}{$\begin{array}{c}\text { Social } \\
\text { Skills }\end{array}$} \\
\hline & $\mathbf{r}$ & $\mathbf{p}$ & $\mathbf{R}$ & $\mathbf{P}$ & $\mathbf{r}$ & $\mathbf{p}$ & $\mathbf{r}$ & $\mathbf{p}$ \\
\hline $\begin{array}{l}\text { Total Call Centre } \\
\text { Environment }\end{array}$ & 0,499 & $<0,001$ & 0,535 & $<0,001$ & 0,443 & $<0,001$ & 0,526 & $<0,001$ \\
Client services & 0,485 & 0,001 & 0,604 & $<0,001$ & 0,449 & 0,002 & 0,508 & $<0,001$ \\
Sales & 0,421 & 0,003 & 0,436 & 0,002 & 0,402 & 0,005 & 0,387 & 0,007 \\
Administration & 0,620 & $<0,001$ & 0,633 & $<0,001$ & 0,504 & $<0,001$ & 0,658 & $<0,001$
\end{tabular}

Table 5 clearly reveals that the emotional competency self-confidence was shown to have the strongest correlation with job performance in the total call centre environment $(\mathrm{r}=0,597 ; \mathrm{p}<0,05)$, as well as in the administrative environment $(\mathrm{r}=0,730 ; \mathrm{p}<0,05)$. Trustworthiness was found to have the strongest correlation with job performance, not only in the client services environment $(\mathrm{r}=0,668 ; \mathrm{p}<0,05)$, but also in the sales environment $(\mathrm{r}=0,539 ; \mathrm{p}<0,05)$.

It was found (Table 6) that the greatest proportion of variance in job performance in the total call centre

environment was explained by the weighted linear combination of emotional self-awareness, trustworthiness, selfconfidence and influence (adjusted R-square $=42,8 \%$ ). Within the client services environment, the weighted linear combination of the emotional competencies emotional selfawareness, trustworthiness, achievement orientation and change catalyst explained the greatest proportion of variance in job performance (adjusted R-square $=60,2 \%$ ). The combination of emotional competencies that explained the greatest proportion of variance in job performance in the sales environment was self-confidence, trustworthiness, empathy, and the development of others (adjusted R-square = $45,7 \%$ ) and in the administrative environment it was self-confidence, trustworthiness, service orientation and accurate self-assessment (adjusted R-square $=60,2 \%$ ).

\section{TABLE 5}

Pearson Correlation COEFFicients for emotional COMPETENCIES AND JOB PERFORMANCE PER DEPARTMENT

\begin{tabular}{|c|c|c|c|c|}
\hline $\begin{array}{l}\text { Emotional } \\
\text { Competencies }\end{array}$ & $\begin{array}{c}\text { Performance } \\
\text { Total } \\
\text { Environment } \\
\mathbf{n}=135\end{array}$ & $\begin{array}{c}\text { Performance } \\
\text { Client } \\
\text { Services } \\
\mathbf{n}=44\end{array}$ & $\begin{array}{l}\text { Performance } \\
\text { Sales } \\
\text { n }=47\end{array}$ & $\begin{array}{c}\text { Performance } \\
\text { Admini- } \\
\text { stration } \\
\mathbf{n}=44\end{array}$ \\
\hline $\begin{array}{l}\text { Emotional self- } \\
\text { awareness }\end{array}$ & $0,330^{*}$ & 0,235 & 0,331 * & $0,463 *$ \\
\hline $\begin{array}{l}\text { Accurate self- } \\
\text { assessment }\end{array}$ & $0,393 *$ & $0,386^{*}$ & $0,336^{*}$ & $0,466^{*}$ \\
\hline Self-confidence & 0,597 * & $0,617^{*}$ & $0,471^{*}$ & $0,730^{*}$ \\
\hline Empathy & $0,354^{*}$ & 0,223 & 0,422 * & 0,459 * \\
\hline Service orientation & $0,330^{*}$ & 0,272 & $0,398^{*}$ & $0,466^{*}$ \\
\hline $\begin{array}{l}\text { Organisational } \\
\text { awareness }\end{array}$ & $0,393 *$ & 0,497 * & 0,253 & 0,483 * \\
\hline Self-control & $0,286^{*}$ & 0,171 & 0,265 & 0,488 * \\
\hline Trustworthiness & $0,527 *$ & $0,668^{*}$ & 0,539 * & $0,459^{*}$ \\
\hline Conscientiousness & $0,447^{*}$ & $0,498^{*}$ & $0,456^{*}$ & $0,572 *$ \\
\hline Adaptability & 0,424 * & 0,373 * & $0,318^{*}$ & $0,582 *$ \\
\hline $\begin{array}{l}\text { Achievement } \\
\text { orientation }\end{array}$ & 0,531 * & $0,642^{*}$ & $0,358^{*}$ & $0,636^{*}$ \\
\hline Initiative & $0,564^{*}$ & 0,581 * & 0,429 * & 0,722 * \\
\hline $\begin{array}{l}\text { Development } \\
\text { of others }\end{array}$ & $0,448^{*}$ & $0,308^{*}$ & $0,304^{*}$ & $0,683^{*}$ \\
\hline Influence & $0,543 *$ & 0,539 * & 0,373 * & $0,639^{*}$ \\
\hline Communication & $0,438^{*}$ & $0,415^{*}$ & $0,325^{*}$ & $0,460^{*}$ \\
\hline Conflict management & it 0,449 * & $0,453^{*}$ & 0,265 & $0,592^{*}$ \\
\hline Leadership & $0,471^{*}$ & $0,495^{*}$ & 0,262 & $0,628^{*}$ \\
\hline Change catalyst & $0,528^{*}$ & $0,570^{*}$ & $0,430^{*}$ & 0,583 * \\
\hline Building bonds & $0,466^{*}$ & $0,350^{*}$ & $0,487^{*}$ & $0,550^{*}$ \\
\hline $\begin{array}{l}\text { Teamwork and } \\
\text { collaboration }\end{array}$ & $0,482^{*}$ & $0,449^{*}$ & $0,413^{*}$ & $0,578^{*}$ \\
\hline
\end{tabular}


TABLE 6

RESULTS OF THE BEST SUB-GROUP REGRESSION

\section{TOTAL ENVIRONMENT:}

Response is Performance

MTB > Regress 'Performance' 4 'E. self-' 'self-confidence' 'Trustworthiness' 'Influence' SUBC > Constant.

Regression Analysis

The regression equation is

Performance $=18,0-7,23$ E. self- $+6,28$ Self-confidence $+6,23$ Trustworthiness $+5,59$ Influence

$\begin{array}{lclcc}\text { Predictor } & \text { Coef } & \text { Stdev } & \text { t-ratio } & P \\ \text { Constant } & 17,992 & 6,125 & 2,94 & 0,004 \\ \text { E. self- } & -7,226 & 1,966 & -3,67 & 0,000 \\ \text { Self-confidence } & 6,285 & 1,894 & 3,32 & 0,001 \\ \text { Trustworthiness } & 6,228 & 1,929 & 3,23 & 0,002 \\ \text { Influence } & 5,590 & 2,070 & 2,70 & 0,008 \\ \text { s }=15,20 & \mathrm{R}-\mathrm{sq}=44,5 \% & \mathrm{R}-\mathrm{sq}(\text { adj })=42,8 \% & \\ \mathrm{R}=0,65 & & & \end{array}$

\section{CLIENT SERVICES:}

The regression equation is

Performance $=-3,2-7,32$ E. self- $+10,3$ Trustworthiness $+7,26$ Achieve or $+4,56$ Change cat

$\begin{array}{lclcc}\text { Predictor } & \text { Coef } & \text { Stdev } & \text { t-ratio } & P \\ \text { Constant } & -3,22 & 10,59 & -0,30 & 0,763 \\ \text { E. self- } & -7,318 & 2,628 & -2,78 & 0,008 \\ \text { Trustworthiness } & 10,324 & 2,424 & 4,26 & 0,000 \\ \text { Achieve or } & 7,263 & 3,038 & 2,39 & 0,022 \\ \text { Change cat } & 4,557 & 3,867 & 1,18 & 0,246 \\ \text { s }=13,21 & \mathrm{R}-\mathrm{sq}=63,9 \% & \text { R-sq(adj) }=60,2 \% & \\ \mathrm{R}=0,78 & \mathrm{z}=1,03 & \text { s.e. }(\mathrm{z})=0,16 & \end{array}$

\section{SALES:}

Regression Analysis

The regression equation is

Performance $=10,2+6,95$ Self-confidence $+9,96$ Trustworthiness $+11,7$ Empathy $-16,5$ Develop others

$\begin{array}{lcccc}\text { Predictor } & \text { Coef } & \text { Stdev } & \text { t-ratio } & \text { P } \\ \text { Constant } & 10,208 & 9,656 & 1,06 & 0,296 \\ \text { Self-confidence } & 6,947 & 2,520 & 2,76 & 0,009 \\ \text { Trustworthiness } & 9,956 & 3,351 & 2,97 & 0,005 \\ \text { Empathy } & 11,667 & 3,490 & 3,34 & 0,002 \\ \text { Develop others } & -16,500 & 4,074 & -4,05 & 0,000 \\ \text { S }=13,81 & \mathrm{R}-\mathrm{sq}=50,5 \% & \text { R-sq(adj) }=45,7 \% & \\ \mathrm{R}=0,68 & \mathrm{Z}=0,82 & \text { s.e. }(\mathrm{z})=0,15 & \\ & & & \end{array}$

\begin{tabular}{|c|c|c|c|c|}
\hline \multicolumn{5}{|c|}{ ADMINISTRATION: } \\
\hline \multicolumn{5}{|c|}{ Regression Analysis } \\
\hline \multicolumn{5}{|c|}{ The regression equation is } \\
\hline \multicolumn{5}{|c|}{ Performance $=9,35-7,69$ Acc. self- $+18,5$ Self-confidence $-8,25$ Trustworthiness $+9,83$} \\
\hline \multicolumn{5}{|l|}{ Service 0} \\
\hline Predictor & Coef & Stdev & t-ratio & $\mathrm{P}$ \\
\hline Constant & 9,349 & 9,802 & 0,95 & 0,346 \\
\hline Acc. self- & $-7,689$ & 3,916 & $-1,96$ & 0,057 \\
\hline Self-confidence & 18,468 & 2,901 & 6,37 & 0,000 \\
\hline Trustworthiness & $-8,248$ & 3,255 & $-2,53$ & 0,015 \\
\hline Service 0 & 9,828 & 3,438 & 2,86 & 0,007 \\
\hline$s=12,98$ & $\mathrm{R}-\mathrm{sq}=63,9 \%$ & R-sq(adj) & $0,2 \%$ & \\
\hline $\mathrm{R}=0,78$ & $z=1,03$ & s.e. $(z)=$ & & \\
\hline
\end{tabular}

\section{DISCUSSION}

Emotional intelligence differentiates average from top performers in the workplace. From the results of this study, it can be concluded that there is a tendency for a high level of job performance in the respective call centres to be associated with a high level of emotional intelligence. This finding also confirms other research findings, that indicate that emotional intelligence is related to job performance in the workplace (Abraham, 1999; Bar-On, 1997; Cavallo \& Brienza, 2002; Cherniss \& Goleman, 1998; Goleman, 1998; Stagg \& Gunter, 2002, Wong \& Law, 2002).

There were no statistically significant differences in the correlations of total emotional intelligence scores and job performance between the respective call centre environments. This could possibly be ascribed to the emphasis on customer focus in most call centres at present. The current high degree of attention to customer centeredness has apparently been applied equally successfully within the customer services, sales and administrative call centre environments within this organisation.

Clusters of emotional intelligence allow assessment of the synergy derived from a combination of emotional competencies that enable exceptional performance (Boyatzis, Goleman \& Rhee, 2000; McClelland, 1998). The results of this study indicate that the cluster of self-management shows the strongest relationship with job performance in both the client services and the sales environments, as well as in the call centre as a whole. This suggests that selfmanagement is directly related to performance in these environments. This finding emphasises the importance of managing one's emotions through self-discipline, integrity, and motivation towards goals in order to perform at optimal effectiveness. It could be inferred from these results that the competencies in the self-management cluster operate together in an integrated fashion, forming a meaningful pattern of abilities that facilitates successful performance in the call centre environment.

There are a number of possible explanations for the statistically significant and positive relationship between job performance and the emotional competencies trustworthiness and self-confidence. Although familiarity with a well-respected company name can denote trustworthiness, most clients base their trust on the performance of the employees of the company with whom they come into contact. The important role played by trustworthiness in the job performance of call centre agents can possibly be attributed to the fact that products or services are offered to clients telephonically in this environment. Most clients will accept telephonic service delivery or product purchasing only if they perceive the relevant call centre agent as someone who acts irreproachably and, above all, ethically. When self-confidence is projected telephonically, it instils a feeling of security and safety in the client. It enables a call centre agent to act assertively without sounding arrogant or defensive. Only those agents that believe in their own competencies appear to have the ability to persuade others to have confidence in them and in the organisation they represent.

The multiple regression analysis of job performance has provided a combination of emotional competencies that explain the greatest proportion of variance in job performance. As each of these emotional competencies explains unique variances in job performance not explained by the other individual emotional competencies included in the regression model, they could be combined usefully in selection procedures for call centre agents to guide the appointment of the most promising candidates. 


\section{CONCLUSION, LIMITATIONS AND RECOMMENDATIONS}

It can be concluded that emotional intelligence is related to job performance in the workplace - in this instance in a call centre environment.

Research has shown that emotional intelligence can be developed and improved at any stage of life through a systematic and consistent approach (Perkins, 1995; Bar-On, 1997; Cooper \& Sawaf, 1997; Cherniss \& Goleman, 1998; Goleman, 1998). Therefore, it is recommended that organisations develop training programmes in order to develop the emotional competencies of managers and agents in call centres. Since social and emotional learning is more complex than cognitive learning, training in emotional competencies for the successful development of emotional intelligence in organisations should be undertaken according to specific guidelines (Cherniss \& Goleman, 1998; Goleman, 1998).

The possible practical value of the results of this study lies in the design of a more effective selection procedure for call centre agents; in the recognition and development of competencies that can enhance job performance; and in the possible reduction of absenteeism and staff turnover within the call centre environment. This would not only lead to the greater success of call centre agents as individuals but might also contribute to the effectiveness and economic success of organisations.

In this study, the call centre agents' team managers completed the questionnaires, due to cost and time constraints. This is viewed as a shortcoming and it is therefore suggested that similar studies that also include self-ratings should be undertaken in future. Calculating an average between the team manager's ratings and self-ratings would add to the validity of the scores.

The organisation agreed to make only the total job performance rating available for the purpose of this study. It is recommended that future research in the call centre environment investigates the relationship between emotional intelligence and the multiple variables of job performance. The relevance of emotional intelligence with regard to other predictors of performance in this environment should also be explored.

The results of this study could serve as a useful source of reference in further research. Although these results are industry-specific, they could be used as a basis for further investigation. It is suggested that similar studies be undertaken in economic sectors other than that of the insurance industry in order to broaden the applicability of results concerning the relationship between emotional intelligence and performance in the call centre environment.

\section{REFERENCES}

Abraham, R. (1999). Emotional intelligence in organizations: A conceptualisation. Genetic, Social, and General Psychology Monographs, (125) 2, 209-224.

Armistead, C.G. \& Clark, G. (1992). Customer service and support: Implementing effective strategies. London: Pitman Publishing.

Arnold, M.B. (Ed.) (1970). Feelings and emotion. New York: Academic Press.

Babbie, E. \& Mouton, J. (2001). The practice of said research. Cape Town: Oxford University Press.

Barlow, J. \& Maul, D. (2000). Emotional value: Creating strong bonds with your customers. San Francisco: Berrett-Koehler.

Bar-On, R. (1997). Emotional Quotient Inventory (EQ-i): Technical manual. Toronto, Canada: Multi-Health Systems.
Boyatzis, R.E. (1982). The competent manager: A model for effective performance. New York: John Wiley.

Boyatzis, R.E., Goleman, D. \& Rhee, K. (2000). Clustering competence in emotional intelligence: Insights from the Emotional Competence Inventory (ECI). In R. Bar-On J.D.A. \& Parker (Eds.). Handbook of Emotional Intelligence, 343-362. San Francisco: Jossey-Bass.

Burckle, M. (2000). ECI and MBTI. Hay/McBer Research Report. Boston: Hay/McBer Group.

Cavallo, K. \& Brienza, D. (2002). Emotional competence and leadership excellence at Johnson \& Johnson: The emotional intelligence and leadership study. [online]. Available: http://www.eiconsortium.org/research/ji_ei_study.htm. [2003 January 8].

Cherniss, C. (2001). Emotional intelligence and organizational effectiveness. In C. Cherniss \& D. Golemann (Eds), The Emotionally Intelligent Workplace, 1-13. San Francisco: Jossey-Bass.

Cherniss, C. \& Goleman, D. (1998). Bringing emotional intelligence into the workplace. A technical report issued by the Consortium for Research on Emotional Intelligence in Organizations. Boston: Hay/McBer Group.

Cooper, R.K. \& Sawaf, A. (1997). Executive EQ: Emotional intelligence in leadership and organizations. New York: Berkley.

Cox, D. (1999). Darwinian call centres. Call Centre Solutions, (18) 3, 72-78.

De Waal (2004). Hallo is dit die hulplyn? Platform, Uitgawe 8, Junie/Julie.

Fischer, A. (1998). Success secret: A high emotional IQ. Fortune, (138), 293-298.

Gabbott, M. \& Hogg, G. (1998). Consumers and Services. Chichester: John Wiley.

Gardner, H. (1983). Frames of Mind. New York: Basic Books.

Goleman, D. (1998). Working with emotional intelligence. New York: Bantam.

Hay/McBer (1999a). Emotional Competency Inventory (ECI) Boston: Hay/McBer Group.

Hay/McBer (1999b). Can you assess your own emotional intelligence? Evidence supporting multi-rater assessment. Boston: Hay/McBer Group.

Hay/McBer (2002). Emotional Competence Inventory Technical Manual. Boston: Hay/McBer Group.

Howell, D.C. (1992). Statistical methods for psychology. Boston: DWS Kent.

Hunter, J.E., Schmidt, F.L. \& Judiesch, M.K. (1990). Individual differences in output variability as a function of job complexity. Journal of Applied Psychology, (75), 28-42.

Jacobsen, T. (1998). Strategic assessment: The roadmap for call centre creation and expansion. Call Centre Solutions, (17) 2, 68-69.

Kendal, M.G. \& Stuart, A. (1961). The advanced theory of statistics. London: Griffin.

Leeper, W. (1948). A motivational theory of emotion to replace emotion as disorganised response. Psychological Review, (55), $5-21$.

McClelland, D.C. (1998). Identifying competencies with behavioural-event interviews. Psychological Science, (9) 5 , 331-340.

Morrison, J. (1999), July 2nd. Die sakevoordele van oproepsentrums. Finansies \& Tegniek, 47-48.

Nash, E.L. (1994). Direct marketing: strategy, planning, execution. New York: McGraw Hill.

Perkins, D. (1995). Outsmarting IQ: The emerging science of learnable intelligence. New York: Free Press.

Queck, C. (1999). Stress management in the call centre. Call Centre IQ, (2) 5, 54-60.

Ryback, D. (1997). Putting emotional intelligence to work. Boston: Butterworth-Heinemann.

Salovey, P. \& Mayer, J.D. (1990). Emotional Intelligence. Imagination, Cognition and Personality, (9)3, 185-211.

Servinc, L. (2001). The effect of emotional intelligence on career success. Unpublished Master's Thesis. Istanbul: University of Istanbul. 
Snyder, C.R. \& Lopez, S.J. (2002). Handbook of positive psychology. Oxford: Oxford University Press.

South African call centre industry explodes. (1999). Call Centre $I Q,(2)$ 5, 6-8.

Spencer, L.M. \& Spencer, S.M. (1993). Competence at work: models for superior performance. New York: John Wiley.

Stagg, G. \& Gunter, D. (2002). Emotional intelligence in the fire service. Working paper. London: London Fire Brigade.

Taylor, E.H. (1990). The assessment of social intelligence. Psychotherapy, (27) 3, 445-457.
The Telephone comes to life: The electronic distribution guide (1995). London: Mercantile \& General Reinsurance Company. Vermeulen, S. (2004). How EQ skills can make a difference to the business case. People Dynamics, (22) 5, 8-11.

Weisinger, H. (1998). Emotional intelligence at work. San Francisco: Jossey-Bass.

Williams, G. (2000). When does the call centre bubble burst? Management Today, (16) 6, 43-47.

Wong, C. \& Law, K.S. (2002). The effects of leader and follower emotional intelligence on performance and attitude: An exploratory study. Leadership Quarterly, (13) 3, 243-274. 